\title{
BAHAGIA MENURUT AL-QUR'AN
}

\author{
Muhammad Arwani Rofi'i \\ Sekolah Tinggi Ilmu Al-Qur'an dan Sains Al-Ishlah (STIQSI) \\ Sendangagung Paciran Lamongan \\ Email:mafaza1309@gmail.com
}

\begin{abstract}
Abstrak
Bahagia merupakan suatu hal yang diinginkan oleh semua makhluq yang berakal. Akan tetapi kebahagiaan antara manusia yang satu dengan lainnya berbeda-beda, karena kebahagian relatif sesuai pada tujuan hidup seseorang. Orang yang menginginkan kehidupan dunia yang berkecukupan akan merasa bahagia apabila hal tersebut tercapai. Berbeda dengan orang yang di dunia hanya mencari iman dan takwa. Oleh karena kebahagian tersebut berubah-ubah penulis menginginkan suatu pedoman dari al-Qur'an sebagai sumber utama umat Islam sehingga dapat diketahui hakikat kebahagian. Tujuan penulis adalah menghadirkan ayat-ayat al-Qur'an yang berkaitan dengan kebahagiaan sehingga dapat memahami maksud yang terkandung dalam ayat tersebut. Penelitian ini merupkan jenis penelitian pustaka (library research) dengan menggunakan metode tafsir mawdu'i (tafsir tematik) dengan cara mengumpulkan ayat-ayat yang terkandung di dalamnya arti kebahagiaan. Penulis menggunakan metode content analyst dalam mengolah informasi yang telah diperoleh dari al-Qur'an, kitab-kitab tafsir dan kitab lainnya yang berkaitan. Hasil penelitian menunjukkan terdapat banyak lafal dalam al-Qur'an yang bermakna kebahagiaan. Akan tetapi, penulis hanya berfokus pada kata fariha-yafrahu-farihan dan bentuk-bentuk lainnya yang diambil dari kata tersebut kemudian dikaitkan dengan kata-kata lain yang menunjukkan arti kebahagian. Secara umum al-farih mempunyai arti kebahagiaan namun dalam kesempatan lain juga dapat diartikan kesombongan dan ridha. Mayoritas ayat yang mencantumkan lafal al-farih terdapat dalam surat Makkiyah, hal ini karena kebahagiaan merupakan pondasi utama penguatan iman penduduk Makkah. Bahagia tidak hanya menjadi sifat manusia namun juga termasuk sifat fi 'liyyah Allah. Bahagia dibagi menjadi dua bagian. Pertama, bahagia terpuji seperti bahagianya umat Islam setelah mendapat berita diterimanya taubat mereka setelah terjadinya peristiwa perang Tabuk. Kedua, bahagia tercela seperti pada kasus Karun yang merasa bahagia atas kekuasaan dan hartanya namun jauh dari Allah subhanahu wa ta 'ala.
\end{abstract}

Kata Kunci: Bahagia, al-Farih

\section{A. PENDAHULUAN}

Allah 'azza wa jalla telah menciptakan manusia dengan bentuk terbaik, dan membedakannya dengan makhluq lainnya. Sebagaimana firman Allah dalam surat al-Isra' ayat 70 yang artinya "Dan Sesungguhnya telah Kami muliakan anak-anak Adam, Kami angkut mereka di daratan dan di lautan. Kami beri mereka rezki dari 
yang baik-baik dan Kami lebihkan mereka dengan kelebihan yang sempurna atas kebanyakan makhluk yang telah Kami ciptakan". 1

Selain manusia telah diciptakan dengan penciptaan terbaik, Allah juga membekali manusia shahwat (keinginan). Seperti firman Allah dalam surat Ali 'Imran ayat 14 yang artinya "Dijadikan indah pada (pandangan) manusia kecintaan kepada apa-apa yang diingini, Yaitu: wanita-wanita, anak-anak, harta yang banyak dari jenis emas, perak, kuda pilihan, binatang-binatang ternak dan sawah ladang. Itulah kesenangan hidup di dunia, dan di sisi Allah-lah tempat kembali yang baik (surga)", 2

Manusia mempunyai keinginan-keinginan sebagaimana termaktub dalam terjamah ayat di atas. Apabila tercapai keinginan tersebut maka hasilnya adalah rasa bahagia. Kebahagiaan manusia tampak begitu bervarisasi dan beraneka ragam dikarenakan keaneka ragaman tujuan dan harapan seseorang. Bagi sebagaian orang dapat makan setiap hari merupakan suatu kebahagiaan. Namun bagi sebagian lainnya itu bukanlah suatu kebahagiaan karena baginya kebahagiaan adalah mempunyai mobil mewah dan lain sebagainya.

Jenis kebahagiaan seseorang sangat beraneka ragam yang mungkin saja dilandasi kondisi sosial yang berbeda antara satu dengan lainnya. Selain itu, juga dikarenakan faktor agama, suasana hati dan jiwa. Oleh karena al-Qur'an merupakan sumber utama umat Islam, perlu kiranya kita mengkaji hakikat kebahagiaan menurut al-Qur'an.

\section{B. PEMBAHASAN}

\section{Makna Bahagia}

\section{Pengertian bahagia}

Bahagia dalam bahasa Arab adalah fariha-yafrahu-farihan, kata ini dalam bahasa menurut Ibnu Manzur dalam kitabnya Lisan al-'Arab mempunyai beberapa arti di antaranya adalah:

1) Lawan dari al-huzn (kesedihan)

2) Mendapatkan keringanan dalam hati

${ }^{1}$ al-Qur'an, 17: 70.

${ }^{2}$ al-Qur'an, 03: 14. 
3) Kesombongan

4) Bahagia, senang, gembira. ${ }^{3}$

Sedangkan menurut istilah sebagaimana yang diungkapkan oleh al-Raghib al-Asfahany dalam kitabnya al-Mufradat, al-farih adalah inshirah al-sadr biladzdzah 'ajilah (kegembiraan hati karena adanya kenikmatan yang datang dengan cepat) kebanyakan hal ini terkait pada kenikmatankenikmatan yang berkaitan dengan badan. ${ }^{4}$ Adapun menurut al-Jurjany dalam kitabnya Mu'jam al-Mufradat, al-farih adalah ladzdzah fi al-qalb linayl al-mushtaha (kenikmatan dalam hati karena mendapatkan sesuatu yang diinginkan). ${ }^{5}$ Sedangkan menurut Qayyim al-Jawziyyah dalam kitabnya Madarij al-Salikin, al-farih adalah ladzdzah taqa'u fi al-qalb bi idrak al-mahbub wa nayl al-mushtaha (kenikmatan yang terletak dalam hati karena mengetahui sesuatu yang disukainya dan mendapatkan sesuatu yang diinginkan). ${ }^{6}$

\section{Bentuk-bentuk kata al-farih dalam al-Qur'an}

Kata al-farih dalam al-Qur'an muncul dalam berbagai bentuk sesuai dengan maknanya di antaranya adalah:

a. Kebahagiaan, suka cita, kesenangan, kegembiraan, riang gembira, kegirangan

Hal ini tergambar dalam firman Allah 'azza wa jalla dalam surat Yunus ayat 22 berikut:

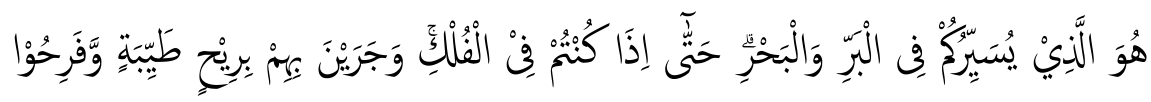

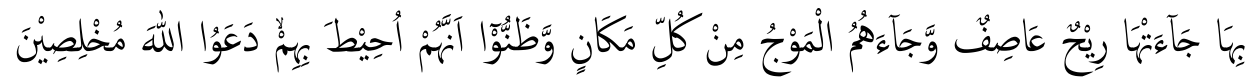

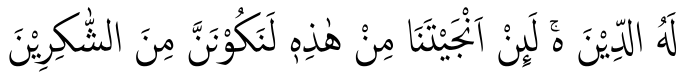

\footnotetext{
${ }^{3}$ Jamal al-Din Muhammad ibn Mukarram ibn Manzur, Lisan al-'Arab Vol II, (Beirut: Dar Sadir, t.th), 541.

${ }^{4}$ Abi al-Qasim al-Husayn ibn Muhammad al-Raghib al-Asfahani, al-Mufradat fi Gharib alQur'an, (t.t: Maktabah Nazar Mustafa al-Baz, t.th), 485.

5 'Ali ibn Muhammad al-Sayyid al-Sharif al-Jurjani, Mu'jam al-Ta'rifat (Kairo: Dar alFadilah, t.th), 139.

${ }^{6}$ Abi 'Abdillah Muhammad ibn Abi Bakr ibn Ayyub Ibn Qayyim al-Jawziyyah, Madarij alSalikin Bayna Manazil Iyyaka Na'budu wa Iyyaka Nasta in Vol III, (Beirut: Dar al-Kutub al'Arabi, 2003), 148.
} 


\section{Muhammad Arwani Rofi'i}

Artinya: Dialah Tuhan yang menjadikan kamu dapat berjalan di daratan, (berlayar) di lautan. sehingga apabila kamu berada di dalam bahtera, dan meluncurlah bahtera itu membawa orang-orang yang ada di dalamnya dengan tiupan angin yang baik, dan mereka bergembira karenanya, datanglah angin badai, dan (apabila) gelombang dari segenap penjuru menimpanya, dan mereka yakin bahwa mereka telah terkepung (bahaya), Maka mereka berdoa kepada Allah dengan mengikhlaskan ketaatan kepada-Nya semata-mata. (mereka berkata): "Sesungguhnya jika Engkau menyelamatkan Kami dari bahaya ini, pastilah Kami akan Termasuk orang-orang yang bersyukur".

b. Kesombongan, keangkuhan

Hal ini tergambar dalam firman Allah 'azza wa jalla dalam surat al-Qasas ayat 76 berikut:

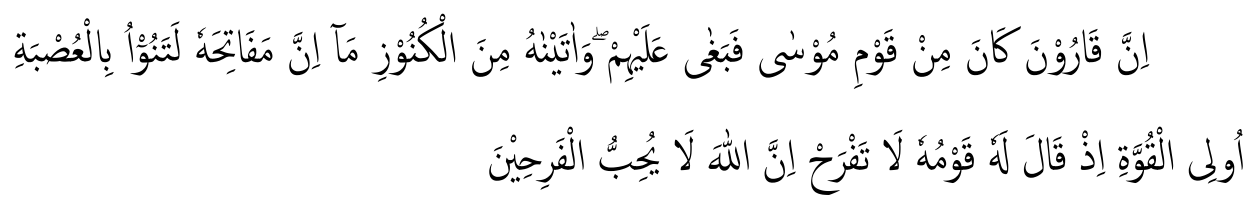

Artinya: Sesungguhnya Karun adalah Termasuk kaum Musa ${ }^{7}$, Maka ia Berlaku aniaya terhadap mereka, dan Kami telah menganugerahkan kepadanya perbendaharaan harta yang kunci-kuncinya sungguh berat dipikul oleh sejumlah orang yang kuat-kuat. (ingatlah) ketika kaumnya berkata kepadanya: "Janganlah kamu terlalu bangga; Sesungguhnya Allah tidak menyukai orang-orang yang terlalu membanggakan diri".

c. Keridlaan, kerelaan

Hal ini tergambar dalam firman Allah 'azza wa jalla dalam surat al-Ra'd ayat 26 berikut:

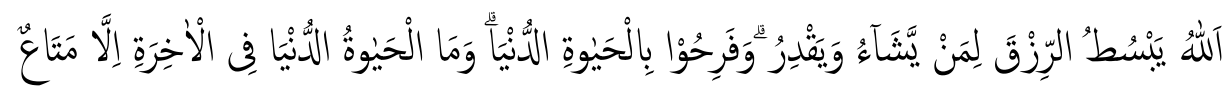

Artinya: Allah meluaskan rezki dan menyempitkannya bagi siapa yang Dia kehendaki. mereka bergembira dengan kehidupan di dunia, Padahal kehidupan dunia itu (dibanding dengan) kehidupan akhirat, hanyalah kesenangan (yang sedikit).

\footnotetext{
${ }^{7}$ [1138] Karun adalah salah seorang anak paman Nabi Musa a.s.
} 


\section{Lafal al-farih dan shigah-shigah-nya dalam al-Qur'an}

\begin{tabular}{|c|c|c|c|c|}
\hline No & Kata & Teks Ayat & $\begin{array}{c}\text { Surat + } \\
\text { Ayat }\end{array}$ & Jenis Surat \\
\hline 1 & فَرِهِيْنَ & 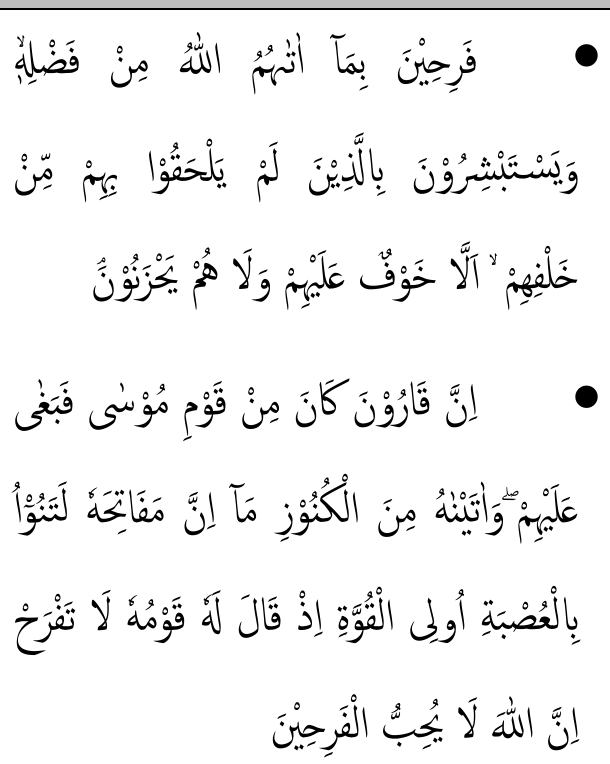 & $\begin{array}{l}\text { Ali 'Imran } \\
170 \\
\text { al-Qasas } 76\end{array}$ & Madaniyyah \\
\hline 2 & يَفْرَحُوْا & 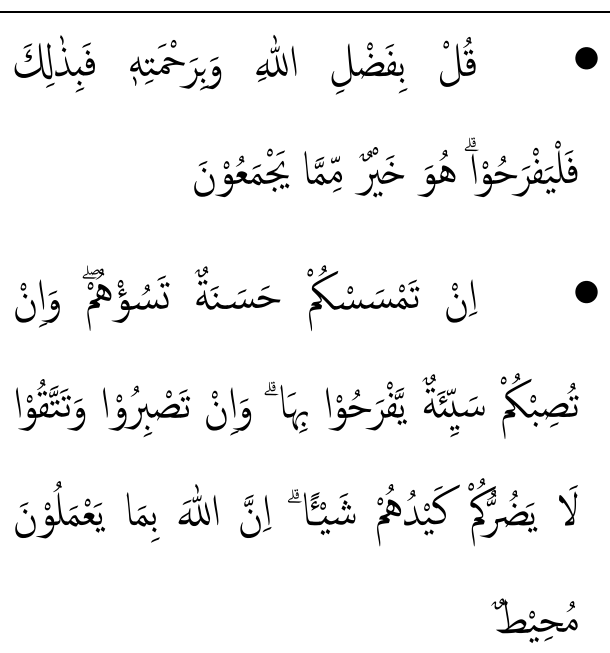 & $\begin{array}{l}\text { Yunus } 58 \\
\text { Ali ‘Imran } \\
120\end{array}$ & $\begin{array}{l}\text { Makkiyyah } \\
\text { Makkiyyah }\end{array}$ \\
\hline 3 & تَفْرَحُوْا & 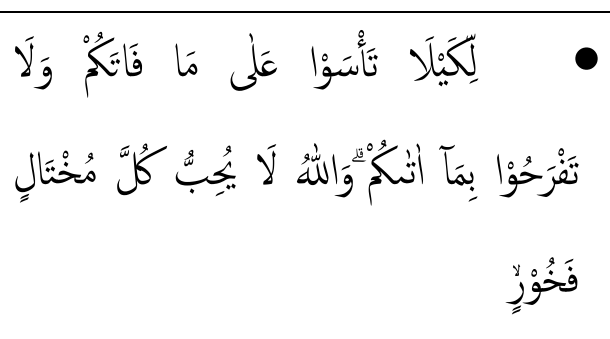 & al-Hadid 23 & Madaniyyah \\
\hline
\end{tabular}




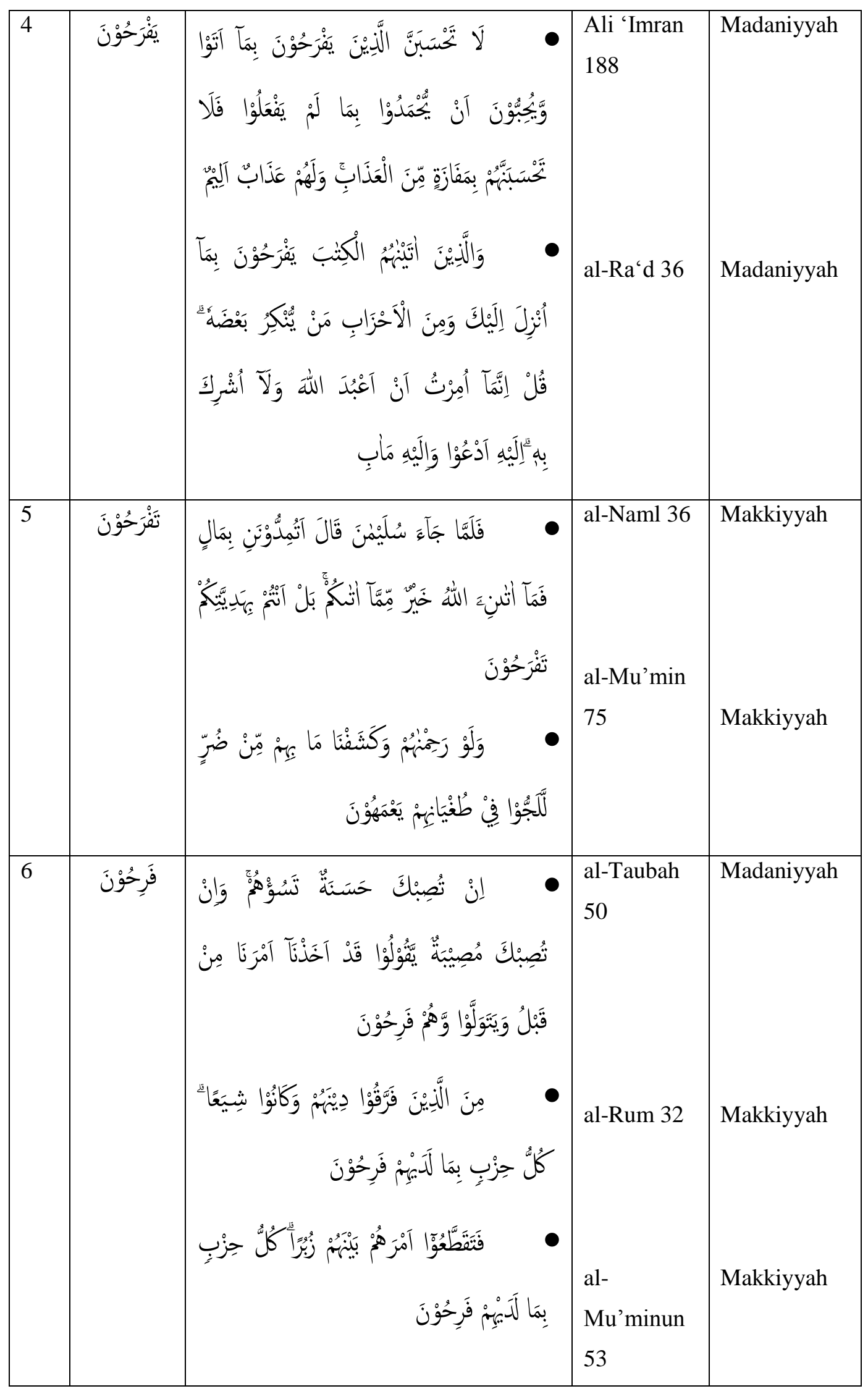


Bahagia Menurut ....

\begin{tabular}{|c|c|c|c|c|}
\hline 7 & فَرَحْ & 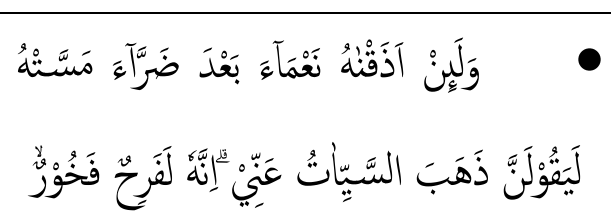 & Hud 10 & Makkiyyah \\
\hline 8 & فَرَحَ & 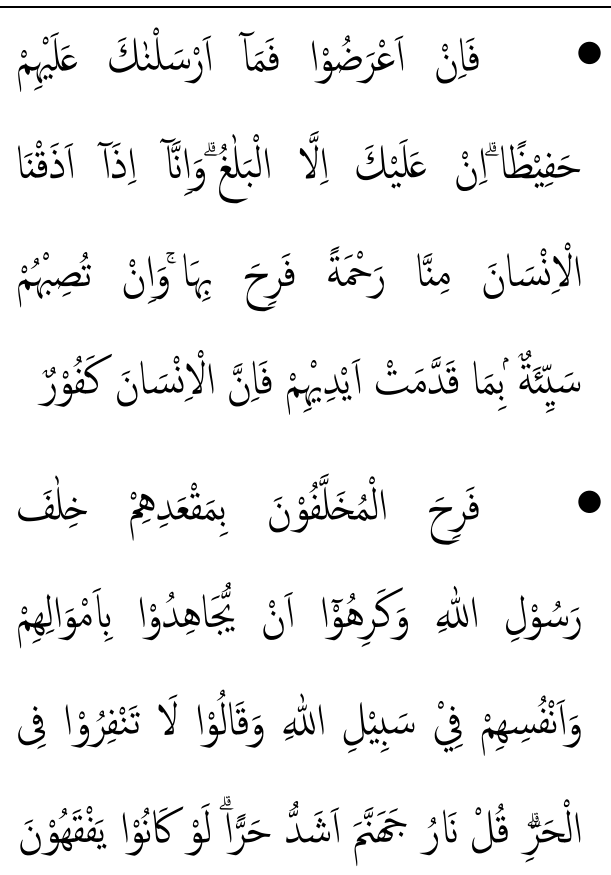 & $\begin{array}{l}\text { al-Shura } 48 \\
\\
\text { al-Taubah } \\
81\end{array}$ & Madaniyyah \\
\hline 9 & يَفْرَحُ & • & al-Rum 4 & Makkiyyah \\
\hline 10 & تَفْزَحُ & 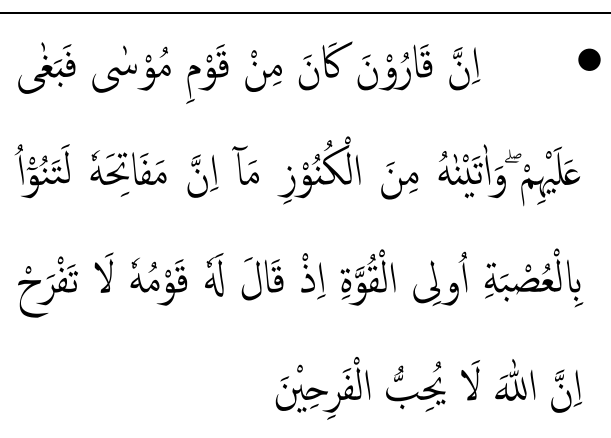 & al-Qasas 76 & Makkiyyah \\
\hline 11 & فَرَحِوْا & 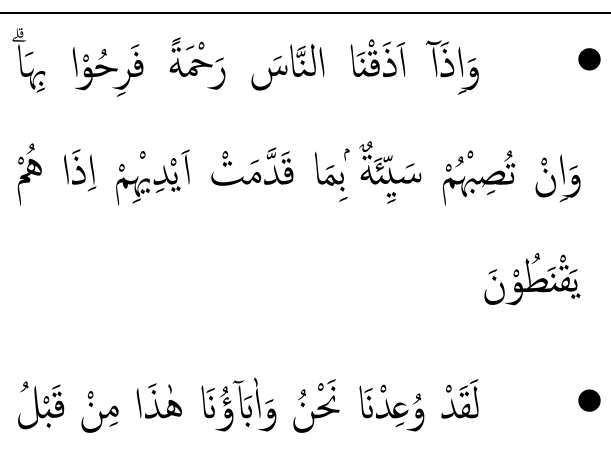 & $\begin{array}{l}\text { al-Rum } 36 \\
\text { al-Mu'min } \\
83\end{array}$ & Makkiyyah \\
\hline
\end{tabular}




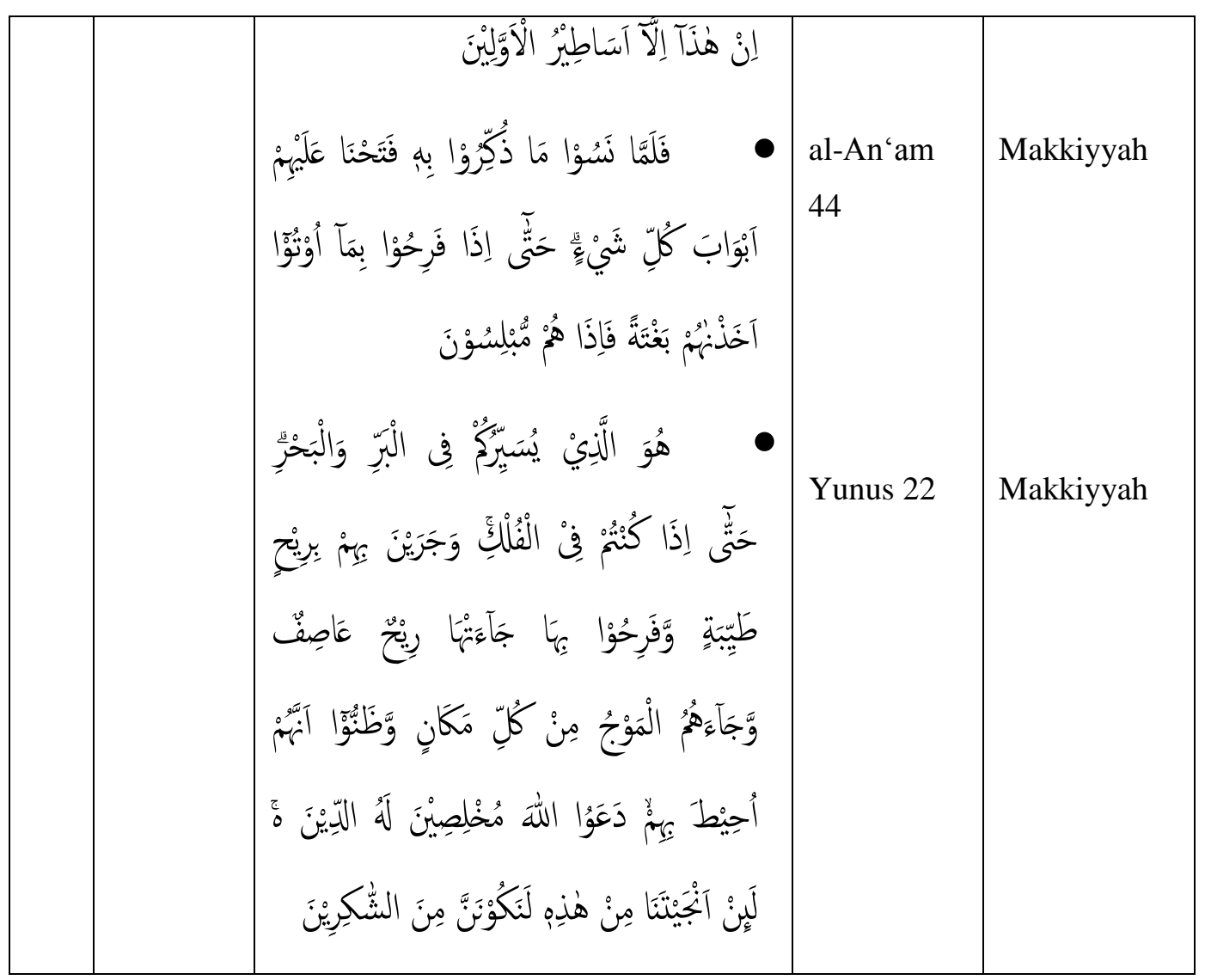

Dari tabel di atas dapat diambil beberapa poin penting di antaranya adalah:

- Kebanyakan surat yang terkandung di dalamnya kata al-farih dan bentukbentuknya adalah surat makkiyyah, hal ini disebabkan karena konteks kebahagiaan berkaitan erat dengan penanaman akidah sebagaimana yang tergambar dalam kebanyakan isi surat makkiyyah yaitu penguatan iman dan pembentukan akidah.

- Kebanyakan ayat yang di dalamnya terdapat al-farih dan bentukbentuknya berkaitan dengan al-dham (celaan) tidak bermakna asli yaitu kebahagiaan. $^{8}$

\section{Lafal-lafal yang berkaitan dengan al-farih}

1) al-Shatm (senang dengan kesusahan orang lain)

Hal ini sebagaimana yang tergambar dalam surat al-A'raf ayat 150 berikut:

\footnotetext{
${ }^{8}$ Ayat Jihad 'Awdah Shayib, al-Farih fi al-Qur'an (Palestina: Maktabah Jami'ah al-Najah alWataniyyah, 2015), 16.
} 


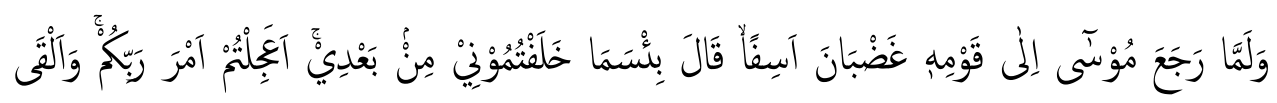

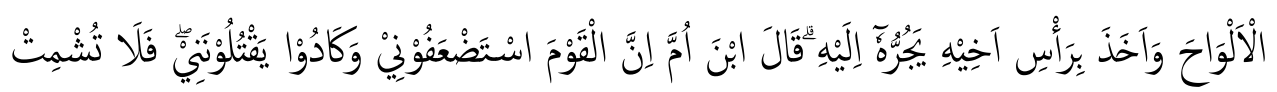

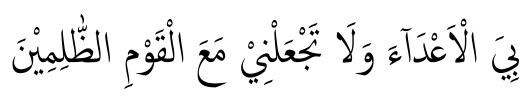

Artinya: dan tatkala Musa telah kembali kepada kaumnya dengan marah dan sedih hati berkatalah dia: "Alangkah buruknya perbuatan yang kamu kerjakan sesudah kepergianku! Apakah kamu hendak mendahului janji Tuhanmu [571] $]^{9}$ dan Musapun melemparkan luh-luh [572] ${ }^{10}$ (Taurat) itu dan memegang (rambut) kepala saudaranya (Harun) sambil menariknya ke arahnya, Harun berkata: "Hai anak ibuku, Sesungguhnya kaum ini telah menganggapku lemah dan Hampir-hampir mereka membunuhku, sebab itu janganlah kamu menjadikan musuh-musuh gembira melihatku, dan janganlah kamu masukkan aku ke dalam golongan orang-orang yang zalim"

2) al-Bishr (kabar gembira)

Lafal ini disebutkan dalam al-Qur'an kurang lebih 53 kali dengan berbagai bentuknya, di antaranya adalah sebagaimana yang Allah firmankan dalam surat al-Baqarah ayat 155 berikut:

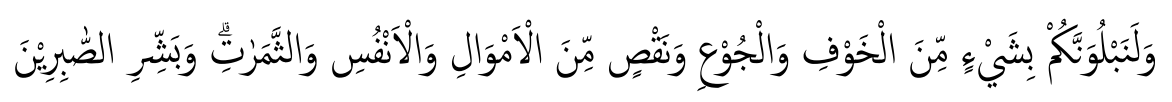

Artinya: dan sungguh akan Kami berikan cobaan kepadamu, dengan sedikit ketakutan, kelaparan, kekurangan harta, jiwa dan buah-buahan. dan berikanlah berita gembira kepada orang-orang yang sabar.

Dan surat al-Anfal ayat 10 berikut:

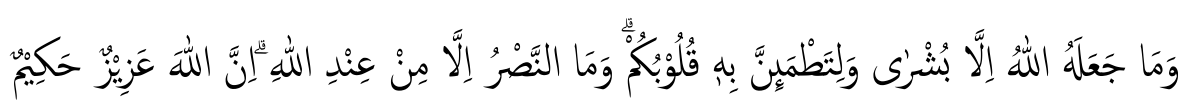

Artinya: dan Allah tidak menjadikannya (mengirim bala bantuan itu), melainkan sebagai kabar gembira dan agar hatimu menjadi tenteram

9 [571] Maksudnya: Apakah kamu tidak sabar menanti kedatanganku kembali sesudah munajat dengan Tuhan sehingga kamu membuat patung untuk disembah sebagai menyembah Allah?.

${ }^{10}$ [572] Luh Ialah: kepingan dari batu atau kayu yang tertulis padanya isi Taurat yang diterima Nabi Musa a.s. sesudah munajat di gunung Thursina. 


\section{Muhammad Arwani Rofi'i}

karenanya. dan kemenangan itu hanyalah dari sisi Allah. Sesungguhnya Allah Maha Perkasa lagi Maha Bijaksana.

3) al-Surur (kegembiraan)

Lafal ini disebutkan sebanyak 4 kali dengan bentuk yang berbeda dalam al-Qur'an di antaranya adalah sebagaimana yang termaktub dalam surat al-Insan ayat 11 berikut:

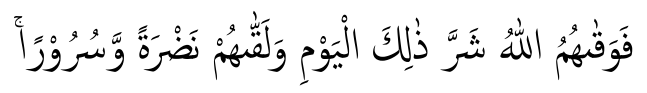

Artinya: Maka Tuhan memelihara mereka dari kesusahan hari itu, dan memberikan kepada mereka kejernihan (wajah) dan kegembiraan hati.

4) al-Sa'adah (kebahagiaan)

Lafal ini disebutkan 2 kali dengan bentuk yang berbeda di antaranya adalah dalam surat Hud ayat 105 berikut:

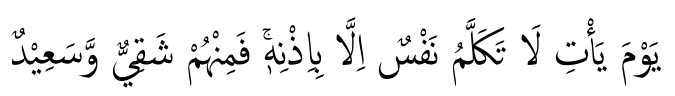

Artinya: di kala datang hari itu, tidak ada seorangun yang berbicara, melainkan dengan izin-Nya; Maka di antara mereka ada yang celaka dan ada yang berbahagia.

5) al-Hubur (suka cita, kesenangan, kebahagiaan)

Lafal ini disebutkan 2 kali dengan bentuk yang berbeda di antaranya adalah dalam surat al-Rum ayat 15 berikut:

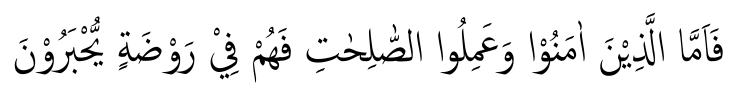

Artinya: Adapun orang-orang yang beriman dan mengerjakan amal saleh, Maka mereka di dalam taman (surga) bergembira.

6) al-Bahjah (suka cita, kesenangan, kebahagiaan, keindahan)

Lafal ini disebutkan 3 kali dengan bentuk yang berbeda di antaranya adalah dalam surat al-Naml ayat 60 berikut:

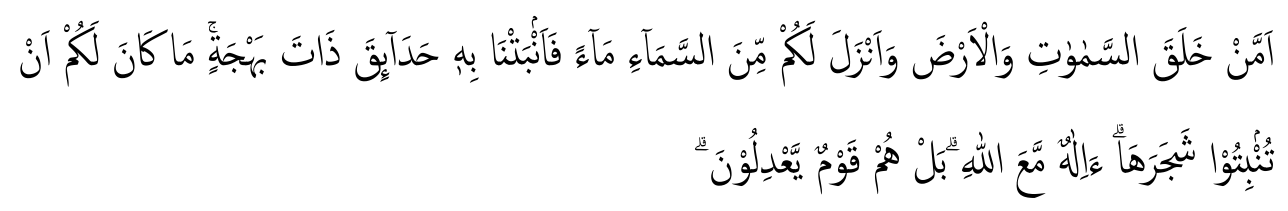

Artinya: atau siapakah yang telah menciptakan langit dan bumi dan yang menurunkan air untukmu dari langit, lalu Kami tumbuhkan dengan air itu 
kebun-kebun yang berpemandangan indah, yang kamu sekali-kali tidak mampu menumbuhkan pohon-pohonnya? Apakah disamping Allah ada Tuhan (yang lain)? bahkan (sebenarnya) mereka adalah orang-orang yang menyimpang (dari kebenaran).

7) al-Dahk (senda gurau, kelekar, guyon)

Lafal ini ada kaitannya dengan al-farih karena kebanyakan tanda kebahagiaan adalah ia dapat bersenda gurau dan tertawa, lafal ini disebutkan 9 kali dengan bentuk yang berbeda di antaranya adalah dalam surat 'Abasa ayat 39 berikut:

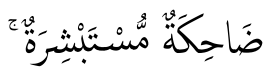

Artinya: tertawa dan bergembira ria,

8) al-Marh (suka ria, riang gembira, girang, periang, senang)

Lafal ini disebutkan 3 kali dengan bentuk yang berbeda di antaranya adalah dalam surat al-Isra' ayat 37 berikut:

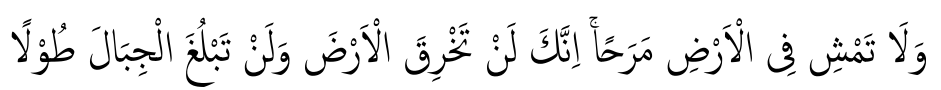

Artinya: yang demikian itu disebabkan karena kamu bersuka ria di muka bumi dengan tidak benar dan karena kamu selalu bersuka ria (dalam kemaksiatan).

\section{Hakikat Kebahagiaan}

\section{a. Sifat bahagia bagi Allah}

Sifat al-farih merupakan salah satu sifat fi liyyah khabariyyah yang tidak dijelaskan dalam al-Qur'an namun ketetapannya terdapat dalam sunnah sahihah yang diterima oleh para ahli hadis, dan dapat dijadikan sandaran ijma' ulama atas penetapan sifat tersebut. Sifat ini menunjukkan kelembutan Allah kepada hambaNya dan rahmat-Nya kepada mereka. Oleh karena itu apabila hamba-Nya bertaubat maka Allah akan menerima taubatnya dan mereka akan merasakan kegembiraan yang sangat dan akan merasakan kelembutan juga dalam satu waktu. Hal ini untuk menjawab hamba-Nya yang tersesat dari ketaatan. Allah 
tidak terbebani (terbahayakan) kemaksiatan hamba-hamba-Nya dan tidak juga termanfaati ketaatan mereka kepada-Nya. ${ }^{11}$

Hadis yang menceritakan tentang sifat al-farih adalah sebagaimana yang diriwayatkan oleh Anas bin Malik berikut:

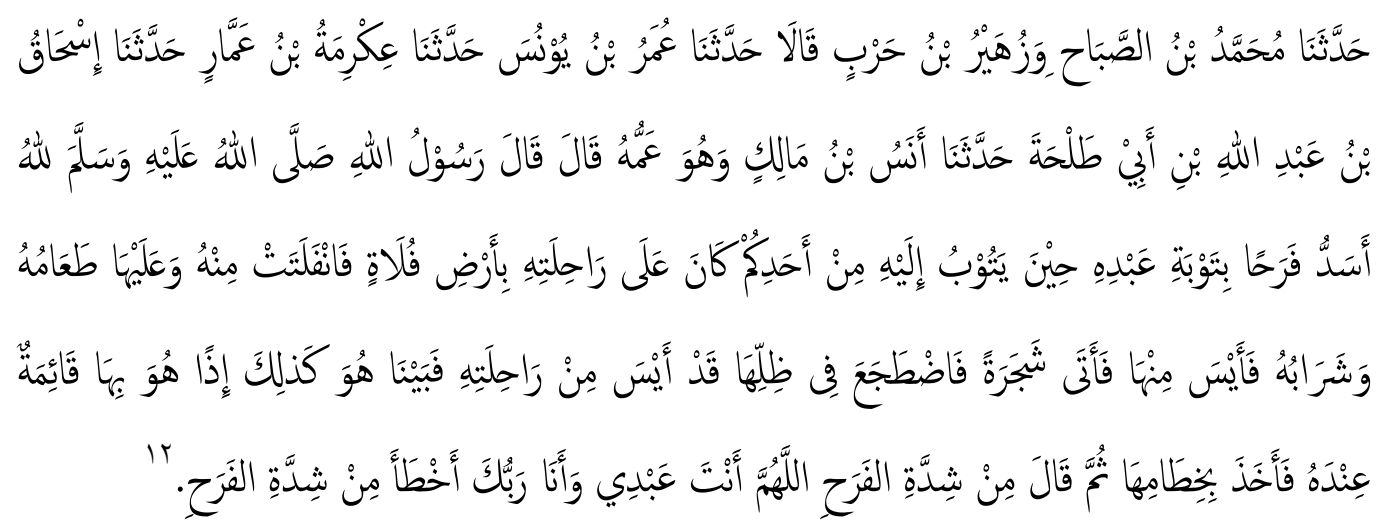

Artinya: Telah menceritakan kepada kami Muhammad ibn al-Sabah da Zuhayr ibn Harb mereka berdua berkata telah menceritakan kepada kami 'Umar ibn Yunus telah menceritakan kepada kami 'Ikrimah ibn 'Ammar telah menceritakan kepada kami Ishaq ibn 'Abdillah ibn Abi Talhah telah menceritakan kepada kami Anas ibn Malik dia adalah pamannya berkata: Rasulullah sallallhu 'alayhi wa sallam bersabda: Sungguh Allah lebih gembira dengan taubat salah seorang dari kalian tatkala ia bertaubat kepada-Nya, dibandingkan dengan kegembiraan seseorang yang berada di atas tunggangannya di suatu tanah yang luas, lalu tunggangannya tersebut lepas, sedangkan makanan dan minumannya pada tunggangannya tersebut. Ia pun putus asa untuk mendapatkan untanya. Maka ia mendatangi suatu pohon dan berbaring di bawah naungan pohon tersebut dan ia sungguh telah berputus asa. Di tengah keadaan itu, ternyata untanya telah ada berdiri di dekatnya. Segera iapun mengambil tali untanya seraya berkata lantaran sangat gembira (wahai Allah kamu adalah hambaku dan aku adalah rabb-Mu) keliru berucap karena terlalu gembira.

\footnotetext{
${ }^{11}$ Muhammad Aman ibn Ali al-Jahi, al-Sifat al-Ilahiyyah fi al-Kitab wa al-Sunnah alNabawiyyah fi Daw'i al-Ithbat wa al-Tanzih, (Madinah: al-Majlis al-'Ilmi, t.th), 297. 210.

${ }^{12}$ Muslim ibn al-Hajjaj, Sahih Muslim Vol IV, (Beirut: Dar al-Kutub al-'Ilmiyyah, 2010),
} 
Hadis ini menunjukkan ketetapan sifat al-farih bagi Allah 'azza wa jalla, pembahasan sifat ini seperti sifat-sifat Allah lainnya. al-Farih merupakan sifat sempurna bagi Allah maka karena Allah disifati dengan hal itu, dan harus dijauhkan dari ta' wil yang mengandung unsur kekurangan. ${ }^{13}$

\section{b. Sifat bahagia bagi manusia}

al-Farih atau kebahagian dianggap sebagai salah satu sifat alami manusia yang dapat dirasakan. Hal ini sebagaimana yang dinyatakan oleh ulama' shu 'ur (ilmuan perasa) bahwasanya sifat ini ditandai dengan terbukanya dada (hati) dan si pemilik hati mendapatkan rasa kenikmatan di hatinya. ${ }^{14}$ Terkadang seseorang dapat menangis dikarenakan kegembiraan yang sangat. ${ }^{15}$

Faktor-faktor yang menyebabkan seseorang berbahagia berbeda-beda antara orang satu dengan lainnya. Oleh karena kebahagian ini adalah hal yang relatif, tergantung pada tujuan sesorang dalam hidupnya. Apabila seseorang tujuannya adalah banyak harta, mendapatkan penguasaaan, mendapatkan kekuatan dan kenikmatan dunia lainnya, maka kesuksesaanya adalah tercapainya tujuan-tujuan tersebut dan hal tersebut menjadikannya bahagia. Sedangkan apabila tujuan hidup seseorang adalah memegang teguh keimanan dan ketakwaan dan amal baik untuk menggapai kebahagiaan maka ia akan mendapatkan kebahagian dengan cara menjaga hal-hal tersebut. ${ }^{16}$

Kebahagiaan hati setidaknya mempunyai 4 sebab yaitu;

1) Kegembiraan, kesenangan dan kebahagiaan hati terhadap Allah dan namanama-Nya, sifat-sifat-Nya, firman-Nya, Rasul-rasulnya dan perjumpaan dengan-Nya.

2) Kebahagiaanya terhadap ilmu yang telah diberikan oleh Allah dari cara berinteraksi kepada-Nya dan ikhlas dan tawakkal kepada-Nya serta percaya sepenuhnya, takut dan berharap hanya kepada-Nya. Jika ini semua tercapai maka kuatlah kebahagiaannya dan kegembiraannya.

\footnotetext{
${ }^{13}$ Abi 'Abdillah Muhammad ibn Abi Bakr ibn Ayyub ibn Qayyim al-Jawziyyah, Madarij alSalikin Bayna Manazil Iyyaka Na'budu wa Iyyaka Nasta in Vol III, (Beirut: Dar al-Kitab al'Arabi, 2003), 150.

${ }^{14}$ Abi 'Abdillah Muhammad ibn Abi Bakr ibn Ayyub ibn Qayyim al-Jawziyyah, Zad al-Ma 'ad fi Hadyi Khayr al- 'Ibad Vol I, (Beirut: Mu'assah al-Risalah, 1998), 177.

${ }^{15} \mathrm{Abi}$ 'Abdillah Muhammad ibn Abi Bakr ibn Ayyub ibn Qayyim al-Jawziyyah, Rawdah alMuhibbin wa Nuzhah al-Mushtaqqin, (Jeddah: Majma‘ al-Fiqh al-Islami, 2013), 150.

${ }^{16}$ Muhammad 'Uthman al-Najati, al-Qur'an wa 'Ilm al-Nafs, (Beirut: Dar al-Shuruq, t.th), 9.
} 
3) Kebahagian yang ditimbulkan karena bertaubat (diterimanya taubat).

4) Kebahagiaan seorang hamba ketika terpisah dari alam dunia dan berjumpa dengan penciptanya dan kemenangannya dengan menggapai ridla dan surgaNya. ${ }^{17}$

Hati yang merasakan manisnya iman termasuk dalam katagori kebahagiaan hati, manisnya iman lebih besar daripada lainnya, sehingga seakan seseorang yang merasakan selainnya tidak mendapatkan kebahagiaan, orang yang sudah merasakan kebahagiaan dari manisnya iman ia tidak lagi membutuhkan kebahagiaan lainnya, hal ini sebagaimana yang Rasulullahsallallhu 'alayhi wa sallam sabdakan dalam hadis berikut:

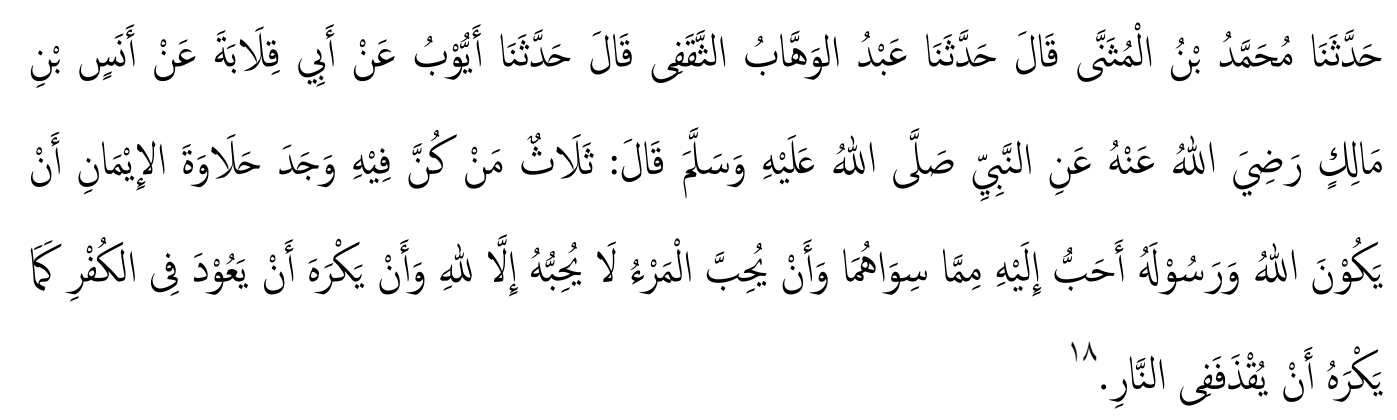

Artinya: Telah menceritakan kepada kami Muhammad ibn al-Muthanna berkata telah menceritakan kepada kami 'Abd al-Wahhab al-Thaqafi berkata telah menceritakan kepada kami Ayyub dari Abi Qilabah dari Anas ibn Malik radiyallahu 'anhu dari Nabi sallallahu 'alayhi wa sallam bersabda: Tiga sifat yang jika ada pada diri seseorang, ia akan mendapatkan manisnya iman, yaitu Allah dan Rasul-Nya lebih ia cintai dari selain keduanya, ia mencintai seseorang tidaklah ia mencintainya kecuali karena Allah, dan ia membenci untuk kembali kepada kekafiran sebagaimana ia membenci dilempar ke dalam api.

\section{Macam-macam Kebahagiaan dan Contohnya}

Ketika kita memperhatikan ayat-ayat al-Qur'an terkait dengan al-farih, kita mendapati bahwasanya al-farih dibagi menjadi dua bagian yaitu al-mahmud (terpuji) dan al-madhmum (tercela), berikut penjelasan kedua bagian tersebut.

\section{a. al-Farih al-mahmud (kebahagian yang terpuji)}

\footnotetext{
${ }^{17}$ Shayib, al-Farih..., 49.

${ }^{18}$ Muhammad ibn Isma‘il al-Bukhari, Sahih al-Bukhari Vol I (Beirut: Dar Ibn Kathir, 2007), 12.
} 
Yaitu setiap keadaan yang mempunyai sebab hukum shar'i(yang telah dibenarkan) untuk berbahagia, baik itu perbuatan ataupun perkataan dhahir (yang tampak) maupun batin (tidak tampak). Apabila kita kembalikan kepada ayat-ayat al-Qur'an terkait al-farih (kebahagiaan) maka akan tampak bahwa kebahagiaan yang terpuji dapat terjadi di dunia maupun di akhirat.

\section{1) Kebahagian yang terpuji di dunia}

Di antara kebahagiaan terpuji yang terjadi di dunia adalah sebagai berikut;

a) Kebahagian atas pertolongan Allah

Contoh yang menggambarkan kebahagiaan karena pertolongan Allah adalah sebagaimana yang Allah firmankan dalam surat al-Rum ayat 1-5 berikut:

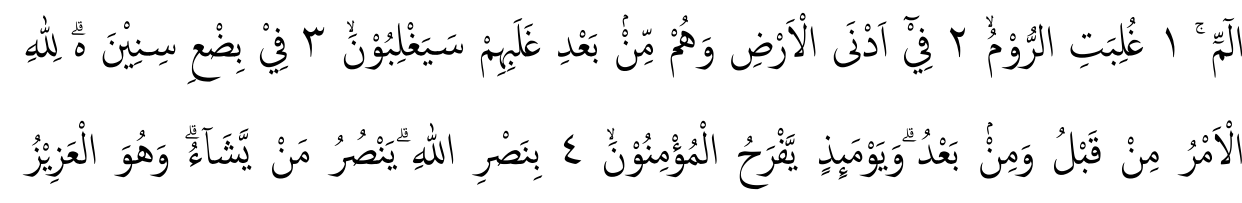

Artinya: (1) Alif laam Miim ${ }^{19}$ (2) telah dikalahkan bangsa Rumawi ${ }^{20}$ (3) di negeri yang terdekat ${ }^{21}$ dan mereka sesudah dikalahkan itu akan menang ${ }^{22}$ (4)

${ }^{19}$ [1160] Ialah huruf-huruf abjad yang terletak pada permulaan sebagian dari surat-surat Al Quran seperti: Alif laam miim, Alif laam raa, Alif laam miim shaad dan sebagainya. diantara Ahliahli tafsir ada yang menyerahkan pengertiannya kepada Allah karena dipandang Termasuk ayatayat mutasyaabihaat, dan ada pula yang menafsirkannya. golongan yang menafsirkannya ada yang memandangnya sebagai nama surat, dan ada pula yang berpendapat bahwa huruf-huruf abjad itu gunanya untuk menarik perhatian Para Pendengar supaya memperhatikan Al Quran itu, dan untuk mengisyaratkan bahwa Al Quran itu diturunkan dari Allah dalam bahasa Arab yang tersusun dari huruf-huruf abjad. kalau mereka tidak percaya bahwa Al Quran diturunkan dari Allah dan hanya buatan Muhammad s.a.w. semata-mata, Maka cobalah mereka buat semacam Al Quran itu.

${ }^{20}$ [1161] Maksudnya: Rumawi timur yang berpusat di Konstantinopel.

21 [1162] Maksudnya: terdekat ke negeri Arab Yaitu Syria dan Palestina sewaktu menjadi jajahan kerajaan Rumawi Timur.

22 [1163] Bangsa Rumawi adalah satu bangsa yang beragama Nasrani yang mempunyai kitab suci sedang bangsa Persia adalah beragama Majusi, menyembah api dan berhala (musyrik). kedua bangsa itu saling perang memerangi. ketika tersiar berita kekalahan bangsa Rumawi oleh bangsa Persia, Maka kaum musyrik Mekah menyambutnya dengan gembira karena berpihak kepada orang musyrikin Persia. sedang kaum muslimin berduka cita karenanya. kemudian turunlah ayat ini dan ayat yang berikutnya menerangkan bahwa bangsa Rumawi sesudah kalah itu akan mendapat kemenangan dalam masa beberapa tahun saja. hal itu benar-benar terjadi. beberapa tahun sesudah itu menanglah bangsa Rumawi dan kalahlah bangsa Persia. dengan kejadian yang demikian nyatalah kebenaran Nabi Muhammad s.a.w. sebagai Nabi dan Rasul dan kebenaran Al Quran sebagai firman Allah. 


\section{Muhammad Arwani Rofi'i}

dalam beberapa tahun lagi ${ }^{23}$, bagi Allah-lah urusan sebelum dan sesudah (mereka menang), dan di hari (kemenangan bangsa Rumawi) itu bergembiralah orang-orang yang beriman (5) karena pertolongan Allah, Dia menolong siapa yang dikehendakiNya, dan Dialah Maha Perkasa lagi Penyayang.

b) Kebahagiaan atas al-Qur'an, Islam dan ilmu

Contoh yang menggambarkan kebahagiaan jenis ini adalah firman Allah dalam surat al-Ra' $\mathrm{d}$ ayat 36 berikut:

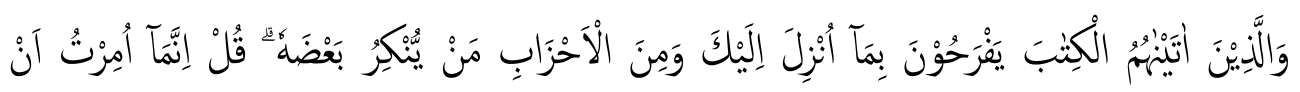

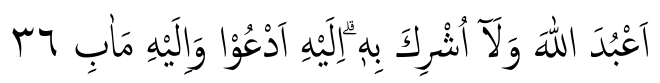

Artinya: orang-orang yang telah Kami berikan kitab kepada mereka ${ }^{24}$ bergembira dengan kitab yang diturunkan kepadamu, dan di antara golongangolongan (Yahudi dan Nasrani) yang bersekutu, ada yang mengingkari sebahagiannya. Katakanlah "Sesungguhnya aku hanya diperintah untuk menyembah Allah dan tidak mempersekutukan sesuatupun dengan Dia. hanya kepada-Nya aku seru (manusia) dan hanya kepada-Nya aku kembali".

\section{2) Kebahagian yang terpuji di akhirat}

Di antara kebahagaian terpuji yang terjadi di akhirat kelak adalah sebagai berikut;

a) Kebahagian sebagai shahid dan mu'min

Hal ini tergambar dalam surat Ali 'Imran ayat 169-171 berikut:

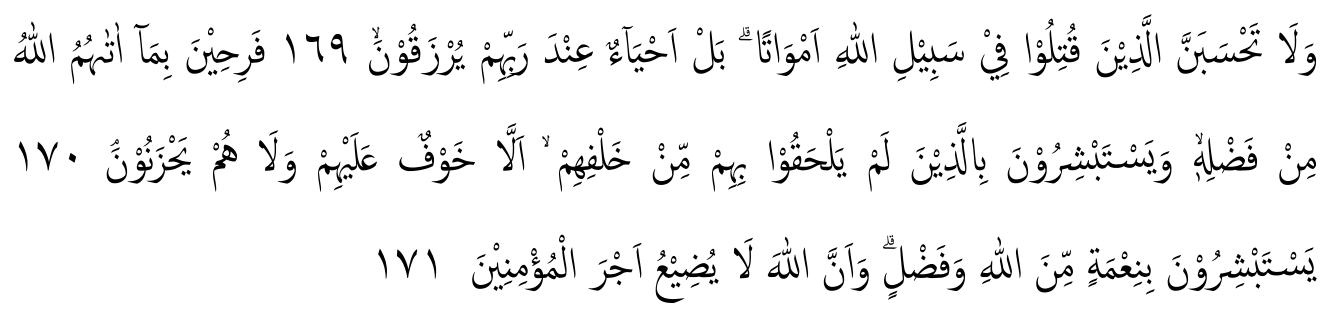

${ }^{23}$ [1164] Ialah antara tiga sampai sembilan tahun. waktu antara kekalahan bangsa Rumawi (tahun 614-615) dengan kemenangannya (tahun 622 M.) bangsa Rumawi adalah kira-kira tujuh tahun.

24 [775] Yaitu orang-orang Yahudi yang telah masuk agama Islam seperti Abdullah bin salam dan orang-orang Nasara yang telah memeluk agama Islam. 
Artinya: (169) janganlah kamu mengira bahwa orang-orang yang gugur di jalan Allah itu mati; bahkan mereka itu hidup ${ }^{25}$ disisi Tuhannya dengan mendapat rezki (170) mereka dalam Keadaan gembira disebabkan karunia Allah yang diberikan-Nya kepada mereka, dan mereka bergirang hati terhadap orang-orang yang masih tinggal di belakang yang belum menyusul mereka $^{26}$, bahwa tidak ada kekhawatiran terhadap mereka dan tidak (pula) mereka bersedih hati (171) mereka bergirang hati dengan nikmat dan karunia yang yang besar dari Allah, dan bahwa Allah tidak menyia-nyiakan pahala orang-orang yang beriman.

al-Farih al-mahmud mempunyai kriteria dan standar, di antara standar atau kriteria tersebut adalah sebagai berikut:

1) Bersyukur

2) Mengingat orang lain yang ada di bawah

3) Mengingatkan diri bahwasanya segala jenis kenikmatan adalah karena karunia Allah

4) Tidak berlebihan dalam melakukan hal-hal yang dibolehkan. ${ }^{27}$

Contoh al-farih al-mahmud yang diabadikan dalam al-Qur'an adalah sebagai berikut;

1) Kebahagian diterimanya taubat orang-orang yang lalai dalam peperangan Tabuk.

Firman Allah dalam surat al-Taubah ayat 117-119 menggambarkan kejadian tersebut:

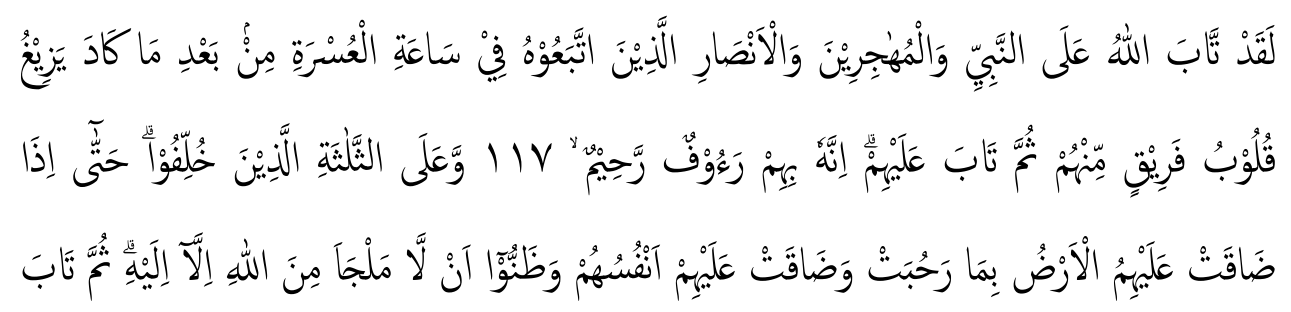

${ }^{25}$ [248] Yaitu hidup dalam alam yang lain yang bukan alam kita ini, di mana mereka mendapat kenikmatan-kenikmatan di sisi Allah, dan hanya Allah sajalah yang mengetahui bagaimana keadaan hidup itu.

${ }^{26}$ [249] Maksudnya ialah teman-temannya yang masih hidup dan tetap berjihad di jalan Allah s.w.t.

${ }^{27}$ Shayib, al-Farih......, 48-51. 


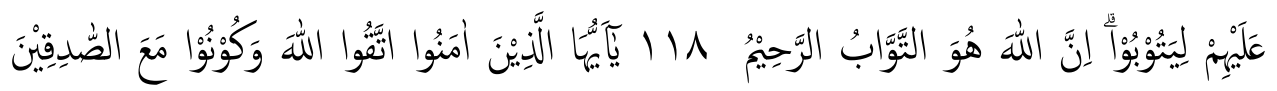
119

Artinya: (117) Sesungguhnya Allah telah menerima taubat Nabi, orangorang muhajirin dan orang-orang anshar yang mengikuti Nabi dalam masa kesulitan, setelah hati segolongan dari mereka hampir berpaling, kemudian Allah menerima taubat mereka itu. Sesungguhnya Allah Maha Pengasih lagi Maha Penyayang kepada mereka, (118) dan terhadap tiga orang ${ }^{28}$ yang ditangguhkan (penerimaan taubat) mereka, hingga apabila bumi telah menjadi sempit bagi mereka, Padahal bumi itu Luas dan jiwa merekapun telah sempit (pula terasa) oleh mereka, serta mereka telah mengetahui bahwa tidak ada tempat lari dari (siksa) Allah, melainkan kepada-Nya saja. kemudian Allah menerima taubat mereka agar mereka tetap dalam taubatnya. Sesungguhnya Allah-lah yang Maha Penerima taubat lagi Maha Penyayang (119) Hai orang-orang yang beriman bertakwalah kepada Allah, dan hendaklah kamu bersama orang-orang yang benar.

2) Kebahagiaan keimanan orang-orang penyihir Fir'aun

Firman Allah dalam surat al-Shu'ara ayat 38-51 menggambarkan kejadian tersebut:

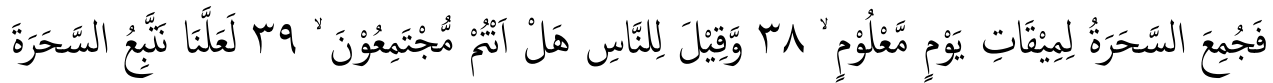

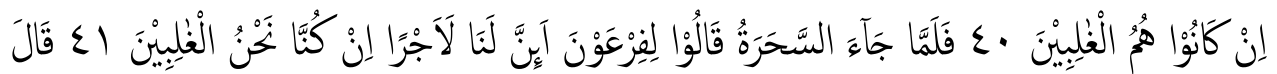

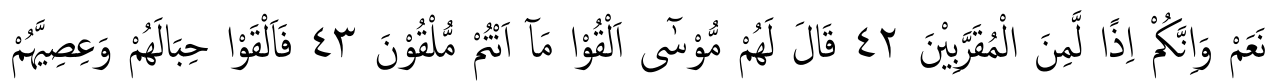

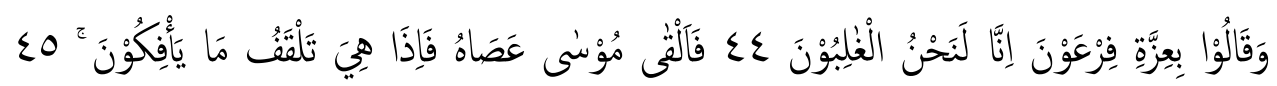

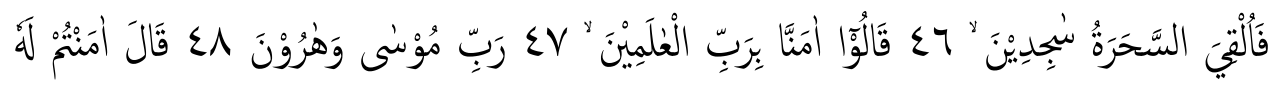

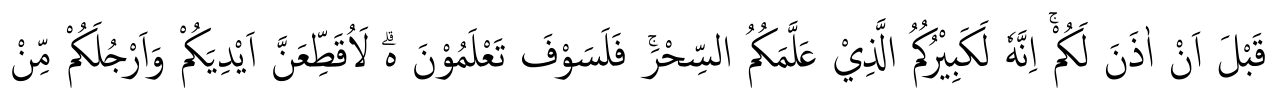

28 [665] Yaitu Ka'ab bin Malik, Hilal bin Umayyah dan Mararah bin Rabi'. mereka disalahkan karena tidak ikut berperang. 


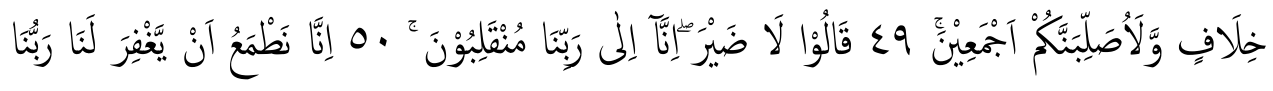
01

Artinya: (38) lalu dikumpulkan Ahli-ahli sihir pada waktu yang ditetapkan di hari yang ma'lum ${ }^{29}$. (39) dan dikatakan kepada orang banyak: "Berkumpullah kamu sekalian. (40) semoga kita mengikuti Ahliahli sihir jika mereka adalah orang-orang yang menang ${ }^{30 " ~(41) ~ M a k a ~}$ tatkala Ahli-ahli sihir datang, merekapun bertanya kepada Fir'aun: "Apakah Kami sungguh-sungguh mendapat upah yang besar jika Kami adalah orang-orang yang menang?" (42) Fir'aun menjawab: "Ya, kalau demikian, Sesungguhnya kamu sekalian benar-benar akan menjadi orang yang didekatkan (kepadaku)". (43) berkatalah Musa kepada mereka: "Lemparkanlah apa yang hendak kamu lemparkan". (44) lalu mereka melemparkan tali temali dan tongkat-tongkat mereka dan berkata: "Demi kekuasaan Fir'aun, Sesungguhnya Kami benar-benar akan menang". (45) kemudian Musa menjatuhkan tongkatnya Maka tiba-tiba ia menelan benda-benda palsu yang mereka ada-adakan itu ${ }^{31}$ (46) Maka tersungkurlah Ahli-ahli sihir sambil bersujud (kepada Allah), (47) mereka berkata: "Kami beriman kepada Tuhan semesta alam, (48) (yaitu) Tuhan Musa dan Harun". (49) Fir'aun berkata: "Apakah kamu sekalian beriman kepada Musa sebelum aku memberi izin kepadamu? Sesungguhnya Dia benarbenar pemimpinmu yang mengajarkan sihir kepadamu Maka kamu nanti pasti benar-benar akan mengetahui (akibat perbuatanmu); Sesungguhnya aku akan memotong tanganmu dan kakimu dengan bersilangan ${ }^{32}$ dan aku akan menyalibmu semuanya". (50) mereka berkata: "tidak ada kemudharatan (bagi kami); Sesungguhnya Kami akan kembali kepada Tuhan Kami, (51) Sesungguhnya Kami Amat menginginkan bahwa Tuhan

\footnotetext{
${ }^{29}$ [1080] Yaitu di waktu pagi di hari yang dirayakan.

30 [1081] Maksudnya: ialah bahwa mereka mengharapkan benar- benar ahli sihir Itulah yang akan menang.

31 [1082] Maksudnya: tali temali dan tongkat-tongkat yang dilemparkan ahli sihir itu yang terbayang seolah-olah menjadi ular, semuanya ditelan oleh tongkat Musa yang benar-benar menjadi ular.

32 [1083] Maksudnya: memotong tangan kanan dan kaki kiri atau sebaliknya.
} 
Kami akan mengampuni kesalahan Kami, karena Kami adalah orangorang yang pertama-tama beriman".

\section{b. al-Farih al-madhmum (kebahagiaan yang tercela)}

Tatkala kita merujuk pada al-Qur'an dan mencari pembahasan tentang tema al-farih al-madhmum, kita akan mendapati bahwa al-farih jenis ini banyak sekali bentuknya, yang dapat kita ringkas menjadi 3 tema utama, yaitu:

\section{1) Kebahagiaan atas dunia beserta isinya}

Kebanyakan ayat yang menjelaskan al-farah al-madhmum adalah masuk dalam katagori ini, dan katagori ini dapat dibagi menjadi dua bagian, yaitu:

a) Kesombongan dan keangkuhan

Hal ini tergambar dalam surat al-Qasas ayat 76 berikut:

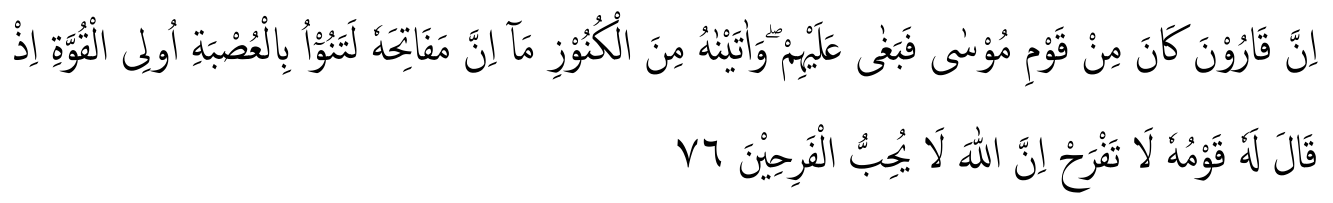

Artinya: Sesungguhnya Karun adalah Termasuk kaum Musa ${ }^{33}$, Maka ia Berlaku aniaya terhadap mereka, dan Kami telah menganugerahkan kepadanya perbendaharaan harta yang kunci-kuncinya sungguh berat dipikul oleh sejumlah orang yang kuat-kuat. (ingatlah) ketika kaumnya berkata kepadanya: "Janganlah kamu terlalu bangga; Sesungguhnya Allah tidak menyukai orang-orang yang terlalu membanggakan diri".

b) Lalai ketika mendapatkan kenikmatan dan putus asa ketika mendapatkan bencana

Di antara ayat yang menjelaskan tentang hal ini adalah dalam surat Yunus ayat 22 berikut:

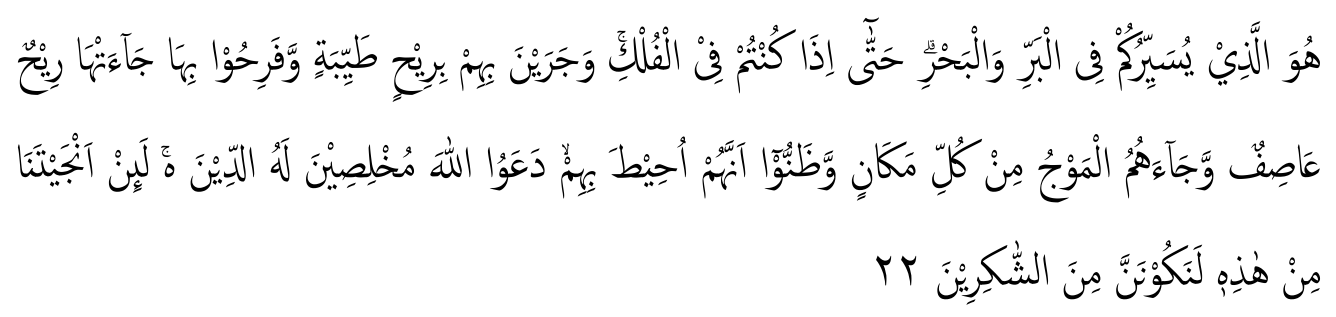

\footnotetext{
${ }^{33}$ [1138] Karun adalah salah seorang anak paman Nabi Musa a.s.
} 
Artinya: Dialah Tuhan yang menjadikan kamu dapat berjalan di daratan, (berlayar) di lautan. Sehingga apabila kamu berada di dalam bahtera, dan meluncurlah bahtera itu membawa orang-orang yang ada di dalamnya dengan tiupan angin yang baik, dan mereka bergembira karenanya, datanglah angin badai, dan (apabila) gelombang dari segenap penjuru menimpanya, dan mereka yakin bahwa mereka telah terkepung (bahaya), maka mereka berdoa kepada Allah dengan mengikhlaskan ketaatan kepada-Nya semata-mata. (mereka berkata): "Sesungguhnya jika Engkau menyelamatkan Kami dari bahaya ini, pastilah Kami akan termasuk orang-orang yang bersyukur".

2) Kebahagiaan orang-orang munafiq atas penderitaan orang-orang mu'min

Hal ini sebagaimana yang Allah firmankan dalam surat Ali 'Imran ayat 120 berikut:

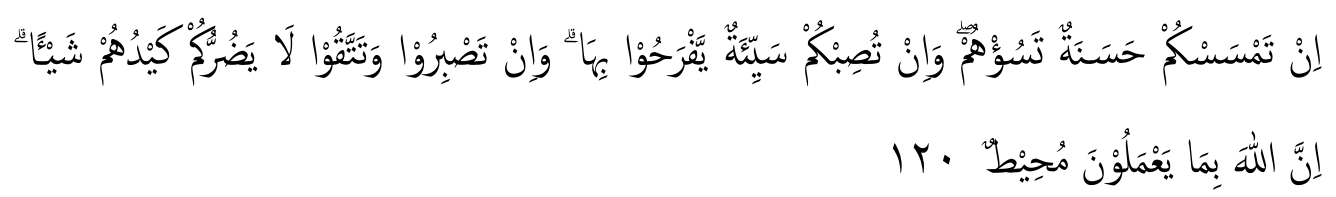

Artinya: jika kamu memperoleh kebaikan, niscaya mereka bersedih hati, tetapi jika kamu mendapat bencana, mereka bergembira karenanya. jika kamu bersabar dan bertakwa, niscaya tipu daya mereka sedikitpun tidak mendatangkan kemudharatan kepadamu. Sesungguhnya Allah mengetahui segala apa yang mereka kerjakan.

3) Kebahagiaan orang-orang kafir atas kelompok mereka, penyembunyian ilmu dan penyelewengannya

Hal ini tergambar dalam surat al-Mu'minun ayat 53 berikut:

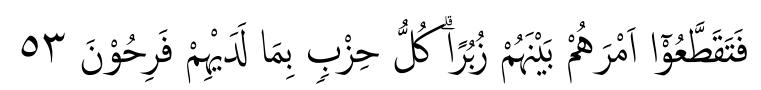

Artinya: kemudian mereka (pengikut-pengikut Rasul itu) menjadikan agama mereka terpecah belah menjadi beberapa pecahan. tiap-tiap golongan merasa bangga dengan apa yang ada pada sisi mereka (masing-masing).

Di antara sebab-sebab al-farihal-madhmum adalah luasnya rizki, seperti pada kasus Karun, dan sedikitnya pemahaman agama serta jeleknya pemahaman atas 
agama. Cara yang dapat digunakan untuk mengobati hal tersebut adalah dengan kembali ke agama Allah yaitu agama Islam. ${ }^{34}$

Contoh al-farihal-madhmum yang terabadikan dalam al-Qur'an adalah:

a) Kebahagiaan Qarun dan kesembongannya atas kekuasaannya dan hartanya

Firman Allah dalam surat al-Qasas ayat 76-83 menggarmbakan hal tersebut

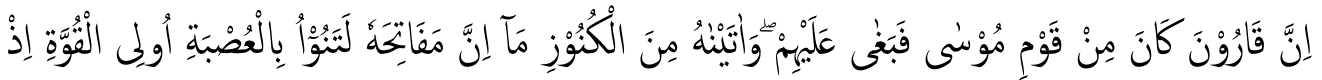

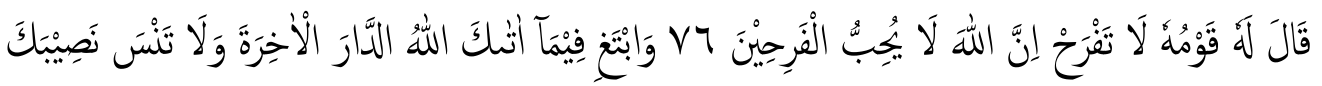

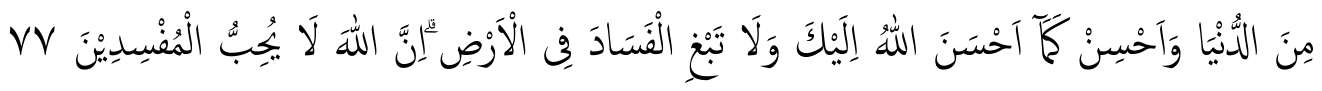

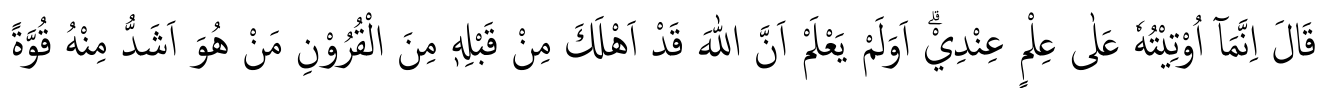

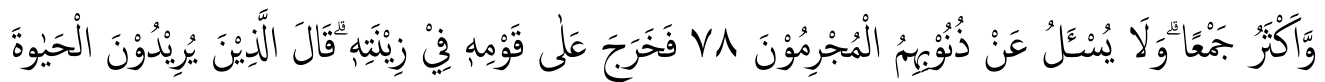

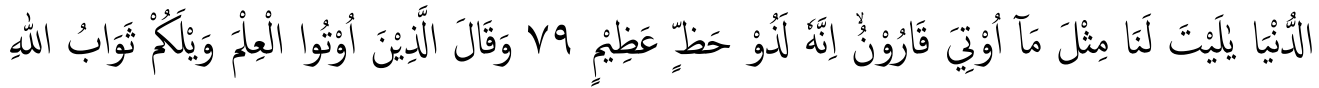

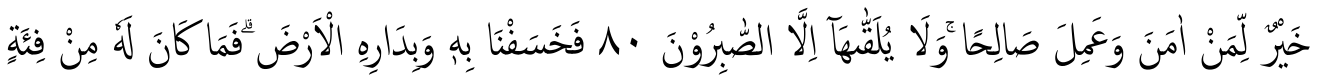

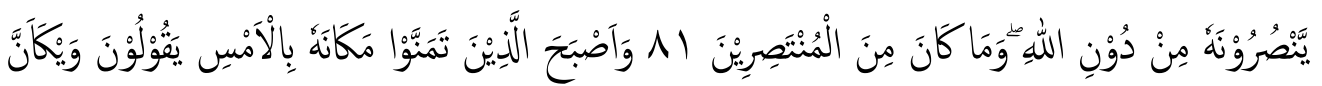

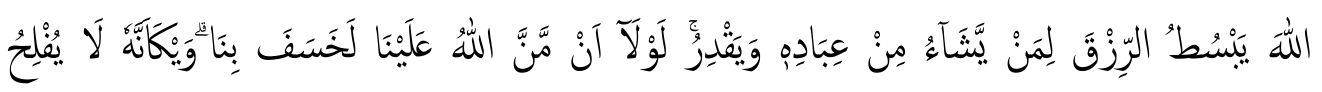

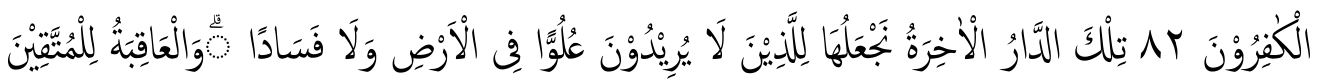

Artinya: (76) Sesungguhnya Karun adalah Termasuk kaum Musa ${ }^{35}$, maka ia Berlaku aniaya terhadap mereka, dan Kami telah menganugerahkan kepadanya perbendaharaan harta yang kunci-kuncinya sungguh berat dipikul oleh sejumlah orang yang kuat-kuat. (ingatlah) ketika kaumnya berkata kepadanya: "Janganlah kamu terlalu bangga; Sesungguhnya Allah tidak menyukai orang-orang yang terlalu membanggakan diri". (77) dan carilah pada apa yang telah dianugerahkan Allah kepadamu (kebahagiaan) negeri akhirat, dan janganlah kamu melupakan bahagianmu dari (kenikmatan)

\footnotetext{
${ }^{34}$ Shayib, al-Farih....., 63.

${ }^{35}$ [1138] Karun adalah salah seorang anak paman Nabi Musa a.s.
} 
duniawi dan berbuat baiklah (kepada orang lain) sebagaimana Allah telah berbuat baik, kepadamu, dan janganlah kamu berbuat kerusakan di (muka) bumi. Sesungguhnya Allah tidak menyukai orang-orang yang berbuat kerusakan. (78) Karun berkata: "Sesungguhnya aku hanya diberi harta itu, karena ilmu yang ada padaku". dan Apakah ia tidak mengetahui, bahwasanya Allah sungguh telah membinasakan umat-umat sebelumnya yang lebih kuat daripadanya, dan lebih banyak mengumpulkan harta? dan tidaklah perlu ditanya kepada orang-orang yang berdosa itu, tentang dosa-dosa mereka. (79) Maka keluarlah Karun kepada kaumnya dalam kemegahannya ${ }^{36}$. berkatalah orang-orang yang menghendaki kehidupan dunia: "Moga-moga kiranya kita mempunyai seperti apa yang telah diberikan kepada Karun; Sesungguhnya ia benar-benar mempunyai keberuntungan yang besar". (80) berkatalah orangorang yang dianugerahi ilmu: "Kecelakaan yang besarlah bagimu, pahala Allah adalah lebih baik bagi orang-orang yang beriman dan beramal saleh, dan tidak diperoleh pahala itu, kecuali oleh orang-orang yang sabar". (81) Maka Kami benamkanlah Karun beserta rumahnya ke dalam bumi. Maka tidak ada baginya suatu golonganpun yang menolongnya terhadap azab Allah. dan Tiadalah ia Termasuk orang-orang (yang dapat) membela (dirinya). (82) dan jadilah orang-orang yang kemarin mencita-citakan kedudukan Karun itu, berkata: "Aduhai, benarlah Allah melapangkan rezki bagi siapa yang Dia kehendaki dari hamba-hambanya dan menyempitkannya; kalau Allah tidak melimpahkan karunia-Nya atas kita benar-benar Dia telah membenamkan kita (pula). Aduhai benarlah, tidak beruntung orang- orang yang mengingkari (nikmat Allah)". (83) negeri akhirat ${ }^{37}$ itu, Kami jadikan untuk orang-orang yang tidak ingin menyombongkan diri dan berbuat kerusakan di (muka) bumi, dan kesudahan (yang baik) ${ }^{38}$ itu adalah bagi orang-orang yang bertakwa.

b) Kebahagiaan orang pemilik dua taman surga

36 [1139] Menurut mufassir: Karun ke luar dalam satu iring-iringan yang lengkap dengan pengawal, hamba sahaya dan inang pengasuh untuk memperlihatkan kemegahannya kepada kaumnya.

${ }^{37}$ [1140] Yang dimaksud kampung akhirat di sini ialah kebahagiaan dan di akhirat.

38 [1141] Maksudnya: syurga. 
Firman Allah dalam surat al-Kahfi ayat 32- 44 berikut menggambarkan kisah pemilik dua surga.

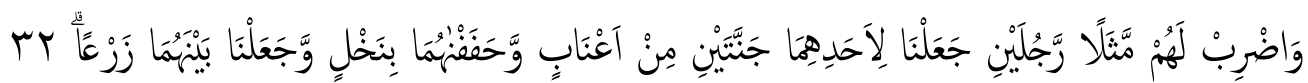

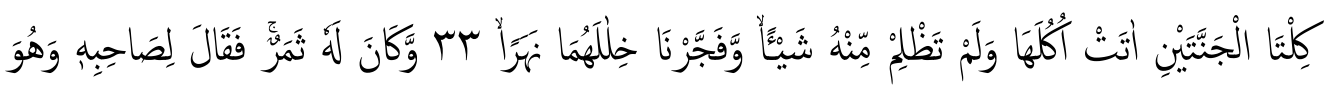

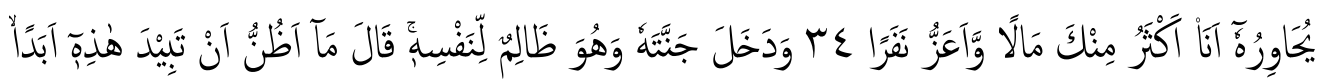

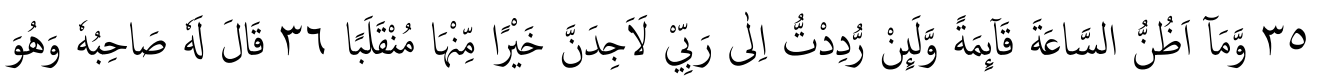

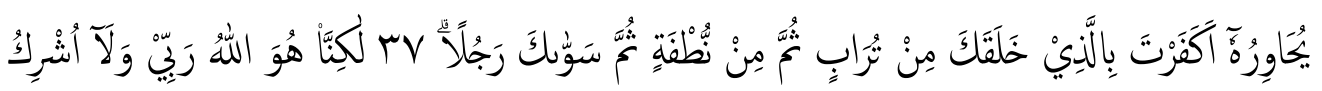

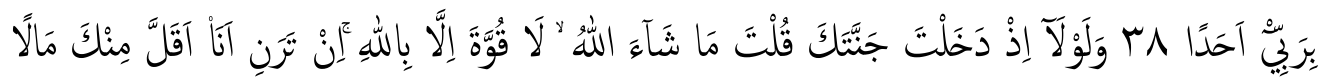

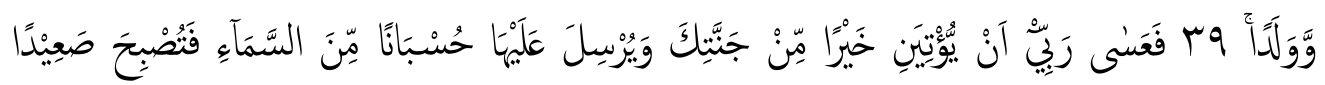

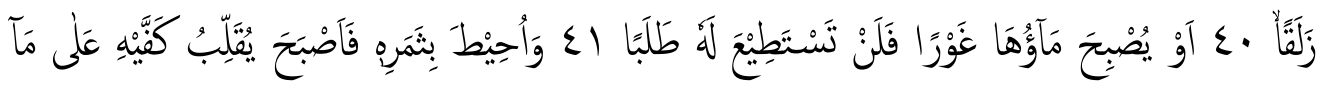

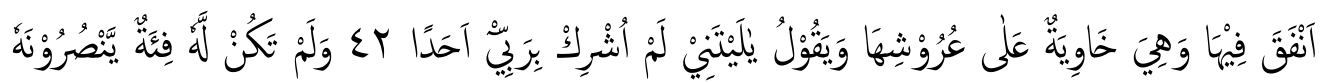

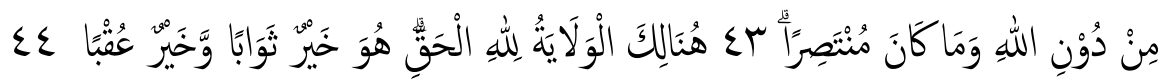

Artinya: (32) dan berikanlah kepada mereka ${ }^{39}$ sebuah perumpamaan dua orang laki-laki ${ }^{40}$, Kami jadikan bagi seorang di antara keduanya (yang kafir) dua buah kebun anggur dan Kami kelilingi kedua kebun itu dengan pohonpohon korma dan di antara kedua kebun itu Kami buatkan ladang. (33) kedua buah kebun itu menghasilkan buahnya, dan kebun itu tiada kurang buahnya sedikitpun, dan Kami alirkan sungai di celah-celah kedua kebun itu, (34) dan Dia mempunyai kekayaan besar, Maka ia berkata kepada kawannya (yang mukmin) ketika bercakap-cakap dengan dia: "Hartaku lebih banyak dari pada hartamu dan pengikut-pengikutku lebih kuat" (35) dan Dia memasuki kebunnya sedang Dia zalim terhadap dirinya sendiri ${ }^{41}$; ia berkata: "Aku kira kebun ini tidak akan binasa selama-lamanya, (36) dan aku tidak mengira hari kiamat itu akan datang, dan jika Sekiranya aku kembalikan kepada Tuhanku, pasti aku akan mendapat tempat kembali yang lebih baik dari pada kebun-

\footnotetext{
${ }^{39}$ [880] Yaitu: kepada orang-orang mukmin dan orang-orang kafir.

40 [881] Yaitu: dua orang Yahudi yang seorang mukmin dan yang lain kafir.

${ }^{41}$ [882] Yaitu: dengan keangkuhan dan kekafirannya.
} 
kebun itu". (37) kawannya (yang mukmin) berkata kepadanya - sedang Dia bercakap-cakap dengannya: "Apakah kamu kafir kepada (tuhan) yang menciptakan kamu dari tanah, kemudian dari setetes air mani, lalu Dia menjadikan kamu seorang laki-laki yang sempurna? (38) tetapi aku (percaya bahwa): Dialah Allah, Tuhanku, dan aku tidak mempersekutukan seorangpun dengan Tuhanku. (39) dan mengapa kamu tidak mengatakan waktu kamu memasuki kebunmu "maasyaallaah, laa quwwata illaa billaah (sungguh atas kehendak Allah semua ini terwujud, tiada kekuatan kecuali dengan pertolongan Allah). Sekiranya kamu anggap aku lebih sedikit darimu dalam hal harta dan keturunan, (40) Maka Mudah-mudahan Tuhanku, akan memberi kepadaku (kebun) yang lebih baik dari pada kebunmu (ini); dan Mudahmudahan Dia mengirimkan ketentuan (petir) dari langit kepada kebunmu; hingga (kebun itu) menjadi tanah yang licin; (41) atau airnya menjadi surut ke dalam tanah, Maka sekali-kali kamu tidak dapat menemukannya lagi". (42) dan harta kekayaannya dibinasakan; lalu ia membolak-balikkan kedua tangannya (tanda menyesal) terhadap apa yang ia telah belanjakan untuk itu, sedang pohon anggur itu roboh bersama para-paranya dan Dia berkata: "Aduhai kiranya dulu aku tidak mempersekutukan seorangpun dengan Tuhanku". (43) dan tidak ada bagi Dia segolonganpun yang akan menolongnya selain Allah; dan sekali-kali ia tidak dapat membela dirinya. (44) di sana pertolongan itu hanya dari Allah yang hak. Dia adalah Sebaikbaik pemberi pahala dan Sebaik-baik pemberi balasan.

\section{KESIMPULAN}

al-Farih atau dalam bahasa Indonesia kebahagian jika merujuk pada makna aslinya. Akan tetapi, kata ini tidak baku karena memiliki beberapa bentuk makna di antaranya adalah kesombongan, keridlaan dan lainnya. Surat-surat yang menyebutkan kata al-farih dan sighah-shighah-nya kebanyakan adalah surat makkiyyah, karena kebahagiaan erat kaitannya dengan penguatan Iman seorang muslim, yang hal tersebut terjadi di awal masa Islam yaitu di Makkah.

al-Farih juga termasuk salah satu sifat Allah fi 'liyyah yang harus kita ketahui, oleh karena itu dalam menta'wilkan sifat tersebut harus dijauhkan dari hal-hal 


\section{Muhammad Arwani Rofi'i}

yang mengandung unsur kekurangan. Dalam al-Qur'an terdapat banyak kisah yang menceritakan tentang kejadian umat terdahulu terkait kebahagian, dari kisahkisah tersebut al-farih dapat dibagi menjadi dua yaitu al-farih al-mahmud seperti pada kisah diterimanya taubat para ahli perang Tabuk dan al-farih al-madhmum seperti pada kisah Karun.

\section{DAFTAR PUSTAKA}

al-Qur'an Karim

Asfahani (al), Abi al-Qasim al-Husayn ibn Muhammad al-Raghib. al-Mufradat $f i$ Gharib al-Qur'an. t.t: Maktabah Nazar Mustafa al-Baz, t.th.

Bukhari (al),Muhammad ibn Isma‘il. Sahih al-Bukhari Vol I. Beirut: Dar Ibn Kathir, 2007.

Hajjaj (al), Muslim ibn. Sahih Muslim Vol IV. Beirut: Dar al-Kutub al-'Ilmiyyah, 2010.

Ibn Manzur, Jamal al-Din Muhammad ibn Mukarram. Lisan al-'Arab Vol II. Beirut: Dar Sadir, t.th.

Jahi (al), Muhammad Aman ibn Ali. al-Sifat al-Ilahiyyah fi al-Kitab wa alSunnah al-Nabawiyyah fi Daw'i al-Ithbat wa al-Tanzih. Madinah: alMajlis al-'Ilmi, t.th.

Jawziyyah (al), Abi 'Abdillah Muhammad ibn Abi Bakr ibn Ayyub Ibn Qayyim. Madarij al-Salikin Bayna Manazil Iyyaka Na'budu wa Iyyaka Nasta in Vol III. Beirut: Dar al-Kutub al-'Ilmiyyah, 2003.

Madarij al-Salikin Bayna Manazil Iyyaka Na‘budu wa Iyyaka Nasta 'in Vol III. Beirut: Dar al-Kitab al-'Arabi, 2003.

Zad al-Ma 'ad fi Hadyi Khayr al-'Ibad Vol I. Beirut: Mu'assah al-Risalah, 1998. 
Rawdah al-Muhibbin wa Nuzhah al-Mushtaqqin. Jeddah: Majma‘ al-Fiqh al-Islami, 2013.

Jurjani (al), 'Ali ibn Muhammad al-Sayyid al-Sharif. Mu 'jam al-Ta'rifat. Kairo: Dar al-Fadilah, t.th.

Najati (al), Muhammad 'Uthman. al-Qur'an wa 'Ilm al-Nafs. Beirut: Dar alShuruq, t.th.

Shayib, Ayat Jihad 'Awdah. al-Farih fi al-Qur'an. Palestina: Maktabah Jami'ah al-Najah al- Wataniyyah, 2015. 